\title{
Globalisation of crime: the electronic dimension
}

\author{
by Rosalind Wright
}

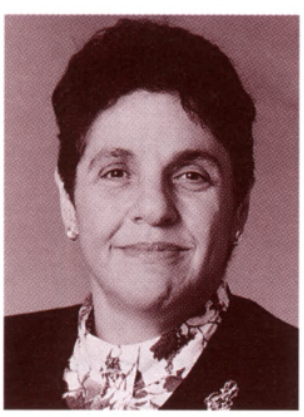

Continuing Sir Ivan Lawrence's theme, discussed in Issue 4 of Amicus Curiae, Rosalind Wright, Director of the Serious Fraud Office, looks at the issues from the electronic and technological viewpoint.

$\mathrm{T}$ he Independent recently described Internet banking as 'a criminal's dream'. A great army of Internet banking services linked with off-shore banking, with their layers of secrecy through which drug money, bribes, proceeds of other major crime and untaxed millions can be moved with ease away from the prying eyes of the authorities, is marching over the electronic horizon, led by the likes of the European Union Bank, recently closed by regulators in Antigua. These entities are hard to pin down to a definable base; harder still to be able to sway the fly-by-nights, the crooks that set them up to prey on the unwary and the tax evader looking for an undetectable haven for black money.

\section{COMPLICATING FACTOR}

Frauds are increasingly multi-jurisdictional in scope. $80 \%$ of all cases investigated by the SFO during the 1996-97 reporting year had a significant foreign element, involving more than one jurisdiction. The fact that every country constitutes a separate and distinct criminal jurisdiction is a complicating factor in any investigation.

\section{WHAT CAN BE DONE?}

What can national regulators do to stem and crush this international epidemic of electronic predators?

One way is to persuade major banking centres which allow offshore business corporations to set up, to recognise that legal professional privilege and banking secrecy laws which were established for the commcrcial protection of legitimate business, are a godsend for the criminal. Also, exceptions and exemptions to that secrecy should be much more readily allowed, to prevent exploitation and abuse by criminals. This applies as much to the traditional banking centres such as Switzerland, Liechtenstein and Austria - which maintain fierce banking secrecy legislation - of which advantage is taken only too often by international crooks, as to the newer centres springing up over the Caribbean and now Eastern Europe too.

Another way is greater recognition of the importance of the checks and safeguards that money laundering controls provide and throughout the world. At present, money laundering directives apply to very few of the centres from which these new predators operate.

London is, of course, the biggest international financial centre in the word and the biggest foreign exchange centre. Consequently, it is crucial that the UK leads the way when it comes to the regulation of financial markets and the criminal processes for fraudsters. Frauds are increasingly multijurisdictional in scope; $80 \%$ of all cases investigated by the Serious Fraud Office (SFO) during the 1996-97 reporting year had a significant foreign element, involving more than one jurisdiction. The fact that every country constitutes a separate and distinct criminal jurisdiction is a complicating factor in any investigation. Fraudsters exploit territorial boundaries and differing legal systems to make the process of investigation and prosecution more complicated and difficult. Internet fraud, in particular, is one aspect of the increasing internationalisation of economic crime.

\section{THE ROLE OF THE SFO}

What part does the SFO play in the fight against the international criminal?

Lord Roskill's fraud trials Report of 1986 (Fraud Trials Committee Report, HMSO 1986) led to the setting up of the SFO in the following year. His vision of a dedicated organisation, with a unique combination of lawyers and accountants working alongside police officers, has proved a durable and effective one.

The SFO fits into the post-Roskill architecture as a unique, focused agency with the task of investigating and prosecuting the tip of the fraud iceberg: those cases which are exceptionally serious and complex. This means that it is limited to a small number of very significant cases - at the moment 82 active cases are under investigation or going through the trial process. The combination of the investigation with the prosecution function enables 'precision tailoring' of enquiries in a major investigation at a much earlier stage than would be the case if the two functions were separated. The SFO model has been adopted by a number of overseas authorities - New Zealand, South Africa and Norway among them - for their own initiatives in tackling serious fraud. 


\section{ASSISTANCE TO OVERSEAS AUTHORITIES}

Section 2 of the Criminal Justice Act 1987 ('CJA'), which provides special, statutory powers enabling the SFO to compel the provision of information, has proved to be a vital tool in getting to the heart of complicated frauds. There is a limitation on the use of evidence, particularly admissions, obtained by use of these compulsory powers. In particular admissions obtained by compulsion cannot be used as primary evidence against the maker. Power to investigate on behalf of overseas authorities and to use the s. 2 powers to aid those authorities was extended (in February 1995) by s. 164 of the Criminal Justice and Public Order Act 1994, amending the Criminal Justice (International Cooperation) Act 1990, to provide assistance in cases where the suspected fraud occurred abroad, but where there has been an involvement in this country. The Home Office retains the right to allow a statement (possibly an admission of the crime), compulsorily obtained by the SFO, to be used at a foreign trial in the same way that it could be used at a UK trial.

As the SFO's reputation in the fight against international crime continues to grow so does its overseas caseload. The number of requests received from foreign counterparts in the financial year 1996-97 grew to 57 from 35 the previous year. Of these, 54 were accepted from 19 countries. Examples of assistance provided include:

- Ex-Italian President Berlusconi: a much publicised mutual legal assistance case. The transfer of documents to Italy was unsuccessfully challenged by the lawyers acting for Berlusconi

- Alan Bond: another mutual legal assistance case which has attracted some publicity. Alan Bond pleaded guilty to fraud charges after an investigation with which the SFO assisted.

- Effex International: in December 1996, the former head of a London-based currency trading scheme, Mr Ostraat, was sentenced to seven years' imprisonment and fined $£ 2.7 \mathrm{~m}$ at Oslo Crown Court - the biggest sentence ever given for fraud in Norway - following an investigation involving close cooperation between the SFO and the Norwegian authorities.

With fraud becoming more international, sophisticated criminals are demonstrating their awareness of and readiness to take advantage of the disparity between the laws and regulations of different jurisdictions. It is therefore more important than ever to emphasise the importance of firm and workable treaties and gateways for mutual assistance (MLATs) and exchange of information between law enforcement agencies. There are a number of MLATs to which the UK is a signatory. The more treaties signed up to and the more gateways opened up across the world, the better, so that there is no safe haven for the international fraudster.

It is equally important to ensure quick, effective arrangements for extradition. Although matters have improved with countries party to the European Convention on Extradition there remains much that can be done to simplify the process. Also, extraterritorial prosecutions where countries refuse to extradite their own nationals are inappropriate in fraud cases. It is impracticable to try these cases in another jurisdiction; it leads to safe havens for fraudsters. The SFO is currently in the process of seeking the extradition of defendants from five jurisdictions in six separate cases; it has successfully secured the return to the UK of defendants in two major fraud cases (one, Abbas Gokal, in the BCCI case).

\section{MORE CO-OPERATION ON THE HOME FRONT?}

What about bringing together those in the UK with an interest in policing, regulating and prosecuting economic malpractice and crime?

Responsibility for different aspects of economic fraud and malpractice is, in the UK, divided between public bodies and regulatory organisations, whose powers to gather evidence, procedures and punishments all differ. The present structure is still fragmented and, because of that, not as efficient as onc would wish.

The new Government's proposed changes in the area of City regulation will inevitably have an impact on the SFO's work. The Government's proposal to unify and consolidate the Financial Services Act regulators, is a welcome first stop towards tackling the problem of fragmentation. Bringing together under the Securities and Investments Board the banking supervisory function of the Bank of England, the building societies and, in due course, Lloyd's of London, is a significant advance. However, the strengthening and greater coherence of the regulatory capability highlights the difficulty faced by the criminal prosecuting authorities. The limitations imposed by the law, court procedures and need to prove beyond reasonable doubt that the accused acted with dishonest intent, create problems in successfully bringing to book some of the most questionable conduct of a commercial nature.

\section{CRITERIA FOR SFO INVESTIGATION}

Criteria for acceptance of a case for investigation by the SFO as 'serious or complex' include:

- the need to use s. 2 of the Criminal Justice Act powers

- significant international dimensions

- likelihood of widespread public concern

- need for highly specialised market knowledge

- normally, whether the sum at risk exceeds $£ 1 \mathrm{~m}$

\section{REGULATION V PROSECUTION}

Is there a role for the FSA to take over responsibility for policing and punishing by disciplinary process some cases of market manipulation or market abuse (including insider dealing) which have proved almost impossible to prosecute? The criminal prosecuting and investigating authorities, including the SFO, could then be left to tackle the more straightforward truly 'criminal' cases.

First of all, it would be wrong to leave the most complicated cases solely with the regulators. What the SFO investigates and brings to court are criminal cases. That is, cases involving dishonesty, deceit, cheating, duplicity - in a word - fraud. The regulators deal, or should deal, with unacceptable market conduct; that is, conduct below the standard one should come to expect in a well-run market. Some of the conduct they examine and discipline practitioners for is substandard because it is negligent; some, because it is unethical. Advantage has been taken of the unwary; there has been concealment of downside factors, of heavy commission charges; there has been 'churning' - too frequent trading to advantage the broker. Real dishonesty should not be the province of the regulator. That is where the criminal authorities have their part to play. 
The regulator cannot really do more than take the offender off the road; deprive him of his licence to operate. That in itself is a very considerable weapon. In many cases, it is depriving a man of his livelihood, and a very lucrative livelihood at that. Where an investment house is taken off the road, it deprives all the employees, the innocent as well as the culpable, of their livelihoods as well. But where dishonesty is involved the public interest requires that a much more severe sanction, deprivation of liberty, is available and public anger is aroused where it feets that a rogue has cheated the public and 'got away with it'.

On the other hand, what are the pitfalls for the criminal prosecutor in tackling market misconduct and market abuse cases, even those which fall fairly and squarely within the category of dishonest behaviour?

\section{THE JURY SYSTEM}

There is the challenge of the jury system. The prosecutor strives to present a complex commercial fraud to a jury of lay people in a way that enables them to understand the intricacies of the commercial transactions and the documents (often the most convoluted and intricate sets of accounts). But this means having to prune a case to its bare essentials losing, in the process, substantial elements of the total criminality alleged.

Even more important than trying to make the case comprehensible for a lay panel, is the problem of manageability of a huge, unvieldy case. For each transaction or series of transactions, or agreements (conspiracies), there are often a number of different combinations of people and facts: hence a number of indictments, that is, a series of trials. If you split the case up into a number of separate units you run the risk of losing the total picture. You are also in danger of the 'Pandora Factor' the ruling by Buckley J to stop the second Maxwell trial in its tracks as 'unfair' on the accused - or, in this case, his wife. If you don't split them, you have an unmanageable monster of a case, like Blue Arrow, where convictions - and there were five convictions in that case - are overturned on appeal as, again 'unfair'; this time on the jury, who were obliged to sit for over a year and deal with indictments against 11 defendants.

One way in which a prosecuting authority can respond to these challenges is to make the management of the case as efficient as possible. Docman is a multi-million pound computer project that the SFO is in the process of introducing, designed to speed investigations and simplify trials. It is an image-based document management system that will handle the huge amounts of material received in the course of investigations and prosecutions.

Again, as a criminal prosecutor, there is the problem of identifying the dishonesty in arcane market practices. But, says the defence, possibly with some justification, 'everybody is doing it' or something like it - or, 'this is innovation and you are not allowing us to compete with our rivals in Japan, the USA, or Europe ...'. We have to find expert witnesses to explain to the jury that the conduct complained of is so totally beyond the pale of acceptability that the defendant must have known it was wrong and deceptive or dishonest. But you are treading warily in between the elephant traps.

\section{TRIAL BY PROFESSIONAL PANEL}

What is the alternative? Trial by a panel of seasoned market professionals, directed by a legal assessor or judge as chairman? That is the pattern of the present regulatory authorities and the Financial Services Tribunal that may be pressed into service for the new unified regulator. A criminal tribunal, headed by a judge and advised by market professionals, has much to recommend it. The proceedings would certainly be curtailed: no need to try and explain at great length what a stock option is, or a rights issue, or a butterfly straddle.

Many people have reservations about such a change. There are lurking fears of defendants' human rights being undermined, even of the creation of an unjust tribunal, answerable only to itself. Conversely, if you are looking for convictions, would the tribunal deliver the goods? Not necessarily is the answer. The fact is that the civil standard of proof applied by the financial services tribunals is very close to the criminal one, when it comes to serious allegations (market manipulation is very serious), or severe sanctions (deriving someone of their livelihood is very severe). A tribunal is as likely as jury to give a defendant the benefit of the doubt and is as prone to be swayed by persuasive and powerful advocacy. There are some exceptionally able and persuasive advocates at the commercial bar who would never set foot in a criminal court

There is the great disadvantage that the regulatory tribunals are not confined to looking for dishonesty. They do and should look for bad behaviour: unsuitable advice, shoddy controls, a lack of due care and diligence. That is where the regulator truly shines. There is no need to prove criminality. That is not their function. If you are looking to save public money, again, the regulatory route certainly is the one to take. No call on the public purse, unless you count the indirect cost to the investor who will have his charges and commissions slightly increased by his stockbroker the next time he buys shares, to pay for the huge fines and costs. The regulator is financed by the financial services industry and will continue to be so in the future. But will they be able to deliver the large fines as well as take licences away in the context of a civil, regulatory tribunal, rather than a criminal court, where the safeguards of not incriminating yourself, the presumption of innocence and the highest standard of proof all apply?

\section{IS THERE AN ALTERNATIVE?}

These approaches - the regulatory and the criminal are starkly divided. Is there an alternative?

Where criminal conduct coincides with regulatory misconduct, the authorities could respond imaginatively, by combining regulatory and criminal penalties in one tribunal. A 'one-stop shop' approach would enhance the effectiveness of both criminal and regulatory authorities by giving the flexibility to dispense penalties which are appropriate to the crimes committed.

Greater flexibility should be introduced in the criminal prosecution and trial of serious and complex fraud, the bulk of which falls, in any event, outside the presently regulated sector. Criminal judges could be armed with some of the regulatory tools that have proved of such benefit in investment regulation, including intervention powers to close down or suspend businesses suspected of being fraudulently run. Punitive fines could be imposed and fraudsters disqualified from taking part in any activity involving the soliciting or managing of investments by the public.

A strengthened criminal process is not a substitute for effective non-criminal regulation. The regulator has a very necessary and distinct role to play and the advantage of a civil standard of proof when enforcing its rules. There will, however, be cases where joint investigations with a regulator can be conducted to the benefit of both. On other occasions, different aspects of the same matter 
will require separate inquiries. These could be made more effective by widening the 'gateways' between the SFO and the regulators.

\section{COMMENDABLE SPEED}

The Law Commission and the Government acted with commendable speed to plug the gap left by the Preddy case, with the Theft (Amendment) Act 1996, which amended s. 15 and 22 of the 1968 Act.

There is plenty of scope for improvement within the criminal justice system itself. In spite of the SFOs efforts to cut the number of charges and concentrate firepower on the key defendant to reduce the time taken to get cases to the point of transfer or committal, trials have still taken too long. More intense efforts on these fronts, coupled with energetic case management by the trial judges, will pay off in terms of shorter and more focused trials. Moving towards a new 'fraud' offence, to replace the plethora of statutory and common law dishonesty and conspiracy offences concerning similar types of fraudulent behaviour, will also help. The SFO is working with other government departments with a prosecuting function to put forward ideas to the Law Commission to reform the law in this area.

Lastly, reverting to the technological element. Law enforcers must ensure that the regulations and procedures move with the times and with the technology. Technology must never be allowed to race ahead so that the law is limping behind to catch up. This is the lesson of the Preddy case ( $R_{V}$ Preddy \& Anor, $R_{v}$ Dhillon [1996] 3 WLR 225 (HL)), where an alleged fraud, which involved the use of a now everyday procedure - the electronic bank transfer of funds - was held by the House of Lords to be outside the ambit of s. 15 of the Theft Acts. The section in question requires proof of obtaining property; the point was that although one chose in action was lessened or extinguished and another created or increased, no property actually passed.

It sounds laughable that such a technical point can bring what appeared to be criminal conduct outside the law. It is actually a very regrettable instance of the law not kecping pace with the technology. The law must be sufficiently flexible and forward looking to cover dishonesty in all its guises. This is why we have argued long and hard for the flexibility that an offence of 'fraud' would give. The law cannot be allowed to be, or to look, an ass.

With the experience of nine years of operation of both the SFO and the Financial Services Act, we can look to more imaginative ways of tackling fraud that even Roskill imagined.

Rosalind Wright

Director, The Serious Fraud Office

\section{Securities Transactions in Europe}

\section{A practical overview of securities transactions}

Written as a 'first-stop' guide for anyone involved in cross-border securities transactions, Securities Transactions in Europe provides an overview of the national systems and regulatory environments governing the securities markets in key European countries.

\section{Benefits to you}

$\checkmark$ Information is provided to enable you to ask the 'right questions' and understand the implications of the answers provided

$\checkmark$ Transaction-based, the service offers invaluable guidance to ensure that you comply with best practice

$\checkmark$ Each country division is similarly structured, so once you are familiar with one country, you are familiar with them all - saving valuable time

$\checkmark$ A Key Points section at the start of each country division provides you with a convenient list of points for each of the other standard chapters within that division

\section{Comprehensive Coverage in one volume} Building to coverage of ten key European countries, the service provides comprehensive information in one compact loose-leaf volume.

\section{Countries covered:}

$\begin{array}{ll}\text { Belgium } & \text { Netherlands } \\ \text { France } & \text { Spain } \\ \text { Germany } & \text { Sweden } \\ \text { Italy } & \text { Switzerland * } \\ \text { Luxembourg } & \text { UK * } \\ & \\ \text { *The service will be expanded in subsequent updates } \\ \text { by the addition of these countries. }\end{array}$

One loose-leaf volume, four updates each year Regular issues of a practical newsletter, including articles and coverage of recent developments

$£ 362$ year one. Call CCH Customer Services on +44(0) 1869253300 or fax +44 (0) 1869874700 to arrange your 28-day trial or to place your order. 